Biol. Proced. Online 2004;6(1): 137-143.

doi: $10.1251 /$ bpo 82

\title{
Use of Ion-Channel Modulating Agents to Study Cyanobacterial $\mathrm{Na}^{+}-\mathrm{K}^{+}$Fluxes
}

\author{
Francesco Pomati², Brendan P. Burns ${ }^{1}$ and Brett A. Neilan ${ }^{1 *}$ \\ 'Cyanobacteria and Astrobiology Research Laboratory, School of Biotechnology and Biomolecular Sciences, \\ The University of New South Wales, Sydney 2052, NSW, Australia. \\ 2Cyanobacteria and Astrobiology Research Laboratory, School of Biotechnology and Biomolecular Sciences, \\ The University of New South Wales, Sydney 2052, NSW, Australia \& Environmental Research Group, DBSF, \\ University of Insubria, via J.H. Dunant 3, 21100 Varese, Italy. \\ *To whom correspondence should be addressed: Brett A. Neilan, Cyanobacteria and Astrobiology Research \\ Laboratory, School of Biotechnology and Biomolecular Sciences, The University of New South Wales, Sydney \\ 2052, NSW, Australia. Phone +61 29385 3235; Fax +61293851591; Email: b.neilan@unsw.edu.au
}

Submitted: May 18, 2004; Revised: June 16, 2004; Accepted: June 17, 2004; Published: June 29, 2004.

Indexing terms: Cyanobacteria; Sodium; Potassium.

Abbreviations: STX, saxitoxin; VTD, veratridine.

\begin{abstract}
Here we describe an experimental design aimed to investigate changes in total cellular levels of $\mathrm{Na}^{+}$and $\mathrm{K}^{+}$ions in cultures of freshwater filamentous cyanobacteria. Ion concentrations were measured in whole cells by flame photometry. Cellular $\mathrm{Na}^{+}$levels increased exponentially with rising alkalinity, with $\mathrm{K}^{+}$levels being maximal for optimal growth $\mathrm{pH}(\sim 8)$. At standardized $\mathrm{pH}$ conditions, the increase in cellular $\mathrm{Na}^{+}$, as induced by $\mathrm{NaCl}$ at $10 \mathrm{mM}$, was coupled by the two sodium channel-modulating agents lidocaine hydrochloride at $1 \mu \mathrm{M}$ and veratridine at $100 \mu \mathrm{M}$. Both the channel-blockers amiloride $(1 \mathrm{mM})$ and saxitoxin $(1 \mu \mathrm{M})$, decreased cellbound $\mathrm{Na}^{+}$and $\mathrm{K}^{+}$levels. Results presented demonstrate the robustness of well-defined channel blockers and channel-activators in the study of cyanobacterial $\mathrm{Na}^{+}-\mathrm{K}^{+}$fluxes.
\end{abstract}

\section{INTRODUCTION}

Cyanobacteria are oxygenic phototrophic prokaryotes that have a cosmopolitan distribution and represent important organisms in all kinds of habitats. The majority of freshwater cyanobacteria are alkaliphilic microorganisms, growing naturally and preferentially at $\mathrm{pH}>8$. In alkaliphilic bacteria, the principal active process employed for the maintenance of cytoplasmic $\mathrm{pH}$ neutrality involves the cycling of ions (mainly $\mathrm{Na}^{+}$and $\mathrm{K}^{+}$) across cell membranes (for review, see (1) and (2)). These mechanisms are also involved in $\mathrm{Na}^{+}$stress resistance. In cyanobacteria, the maintenance of non-toxic intracellular sodium levels $\left(\left[\mathrm{Na}^{+}\right]<10\right.$ $\mathrm{mM})$ and $\mathrm{pH}$ neutrality is achieved by net $\mathrm{H}^{+}$accumulation coupled to $\mathrm{Na}^{+}$efflux as mediated by the $\mathrm{Na}^{+} / \mathrm{H}^{+}$antiporter (3$5)$. This process is energized by an imposed proton motive force (6-7), with uptake of $\mathrm{Na}^{+}$required only in alkaline conditions. $\mathrm{Na}^{+}$uptake can be achieved by general sodium/solute symporters, cation channels $(2,8)$ or $\mathrm{pH}$-gated $\mathrm{Na}^{+}$channels $(3)$. A schematic diagram summarising the proteins involved in the sodium cycle is shown in Fig. 1. Unfortunately, prokaryotic sodium channels and their characteristics remain largely uncharacterized (9-10). 


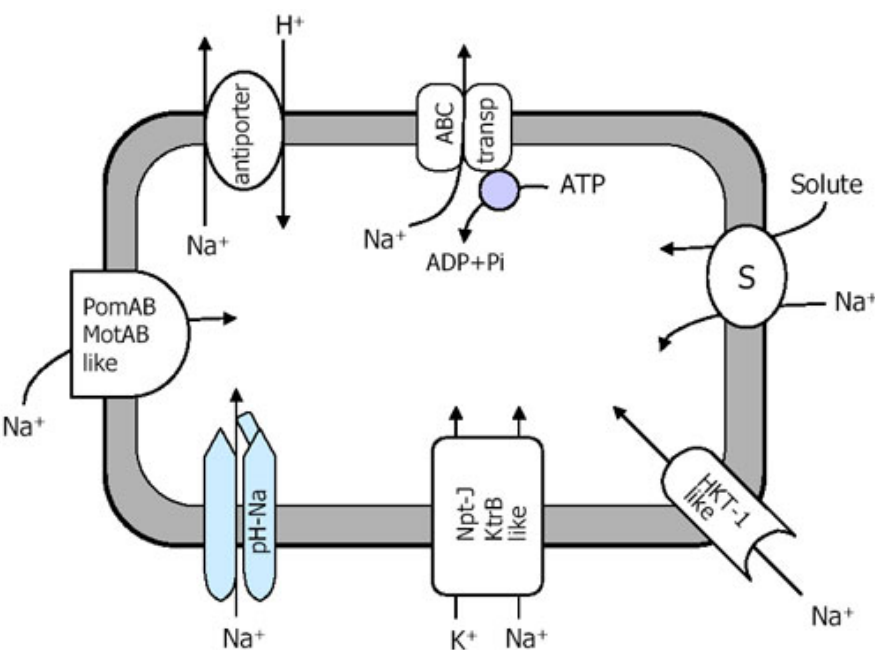

Fig. 1: Primary elements which have defined roles in the $\mathrm{Na}^{+}$cycle and alkaline $\mathrm{pH}$ homeostasis of facultatively alkaliphilic microorganisms. $\mathrm{Na}^{+}$ ions can be removed from the cytosol either by $\mathrm{H}^{+}$exchangers or by ATPdependent ABC-type sodium transporters. $\mathrm{Na}^{+}$uptake can be achieved by sodium/solute symporters and cation channels, such as NtpJ-, KtrB-, MotAB/PomAB-, and HKT-1-like proteins $(2,8,34)$. Homologues of these molecules are present in cyanobacteria $(5,29,34,35)$. The existence of a $\mathrm{pH}$ gated sodium channel $(\mathrm{pH}-\mathrm{Na})$ is also hypothesized (3).

The study of sodium homeostasis can be particularly important in the case of toxic tropical and sub-tropical cyanobacterial species such as Cylindrospermopsis raciborskii and Anabaena circinalis (11-13). These freshwater filamentous cyanobacteria represent the major components of phytoplankton communities in ecosystems that are periodically punctuated by flood and drought periods, with alkaline $\mathrm{pH}$ and increasing salinity being correlated to the occurrence of dense and toxic summer water-blooms (14).

The purpose of this paper is to summarize an approach recently developed and optimized to study cyanobacterial sodium fluxes and related functions. Here we describe the research technique and the experimental design to address the effects of natural conditions ( $\mathrm{pH}$, salt) and channel-modulating agents (amiloride, lidocaine, veratridine, and saxitoxin), on total $\mathrm{Na}^{+}-\mathrm{K}^{+}$cellular levels in the cyanobacterial species Cylindrospermopsis raciborskii. The results presented were obtained by means of flame photometry analysis, and suggest that in C. raciborskii, sodium fluxes are responsive to channel-blockers and channel-activators similar to the extent that has been well-documented for eukaryotic cells.

\section{MATERIALS AND METHODS}

\section{Growth conditions and cyanobacterial cultures}

C. raciborskii strain T3 was kindly provided by Sandra Azevedo (Federal University of Rio de Janeiro, Brazil). C. raciborskii strain AWT205 was obtained from Peter R. Hawkins (Australia Water Technologies, EnSight, West Ryde, NSW, Australia). Both strains were grown in ASM-1 medium (15). Cultures were maintained in glass $250 \mathrm{~mL}$ flasks in a cabinet at a constant temperature of $26^{\circ} \mathrm{C}$ and under continuous irradiance of cool white light at an intensity of $15 \mu \mathrm{mol}$ photon $\mathrm{m}^{-2} \mathrm{~s}^{-1}$. Cultures were monitored spectrophotometrically by recording the optical density at $750 \mathrm{~nm}$ $\left(\mathrm{OD}_{750}\right)$ with a Lambda $10 \mathrm{UV} / \mathrm{VS}$ spectrometer (Perkin Elmer, Inc., Shalton, CT).

\section{Ion-channel modulating agents}

Reagents were obtained from Sigma-Aldrich (Sigma-Aldrich Co., Dorset, UK). Lidocaine hydrochloride and amiloride solutions (100 $\mu \mathrm{M}$ and $100 \mathrm{mM}$, respectively) were prepared freshly in Milli-Q water prior to each experiment and diluted in culture medium to obtain the final concentrations required. Veratridine was dissolved to a final concentration of $10 \mathrm{mM}$ in acidic Milli-Q water $(\mathrm{pH} 2)$ and stored at $-20^{\circ} \mathrm{C}$. Certified standard solutions of saxitoxin (PSP-1C and STX-diHCl-C) were obtained from the Institute of Marine Bioscience (IMB), National Research Council of Canada, Halifax, NS, Canada. Saxitoxin standards were stored at $-20^{\circ} \mathrm{C}$ with the stock solutions diluted into the culture medium to obtain the final test concentrations.

\section{Flame photometry analysis}

Total cellular $\mathrm{Na}^{+}$and $\mathrm{K}^{+}$levels in cyanobacteria were assayed by flame photometry. $\mathrm{Na}^{+}$and $\mathrm{K}^{+}$standard solutions (both 100 $\mathrm{mM}$ ) were prepared fresh every week in $15 \mathrm{~mL}$ Falcon ${ }^{\circledR}$ plastic tubes using sterile Milli-Q water and stored at $4^{\circ} \mathrm{C}$. Prior to calibration, $\mathrm{Na}^{+}$and $\mathrm{K}^{+}$standards were diluted $1 / 200$ in diluent flame solution ( $3 \mathrm{mM} \mathrm{Li}$ in MilliQ water) and immediately analysed. Two millilitre aliquots of $C$. raciborskii cultures were collected and harvested by centrifugation in $2 \mathrm{~mL}$ Eppendorf plastic tubes at $11000 \mathrm{~g}$ for $15 \mathrm{~min}$. All sampled pellets were resuspended in $0.5 \mathrm{~mL}$ of diluent flame solution and immediately analysed for total $\mathrm{Na}^{+}-\mathrm{K}^{+}$cellular content using a FLM3 Flame Photometer (Radiometer, Copenhagen, Denmark).

\section{Statistical analyses}

All experiments were performed in triplicate or quadruplicate. Graphical and descriptive statistical analyses were performed using the software for PC Origin 5.0 (Microcal Software, Inc., Northampton, MA).

\section{RESULTS AND DISCUSSION}

\section{Experimental design}

In this study we chose, as experimental cultures, cyanobacteria in mid-logarithmic growth phase $\left(\mathrm{OD}_{750}=0.3\right.$ to 0.4$)$. Such condition provides a sufficient density of cells to detect changes in cellular ion levels without the physiological constraints induced by higher cell concentrations. To evaluate the effect of $\mathrm{pH}$ on total cyanobacterial $\mathrm{Na}^{+}-\mathrm{K}^{+}$levels, aliquots of the same mid- 
logarithmic culture were adjusted to different $\mathrm{pH}$ and analysed after $2 \mathrm{~h}$. To further study cellular $\mathrm{Na}^{+}-\mathrm{K}^{+}$levels, we chose the optimal conditions for strain growth, corresponding to $\mathrm{pH}>8$, which are also associated with active $\mathrm{Na}^{+}$homeostasis $(1,2)$. Additionally, some channel-blockers such as lidocaine are considered active only when the net charge of the molecule is equal to 0 , which is achieved at alkaline $\mathrm{pH}$ (16). To assay cyanobacteria with the different agents, cultures were adjusted to $\mathrm{pH} 8.1$ by adding HEPES buffer to a final concentration of 10 $\mathrm{mM}$.

Experiments were carried out for $60 \mathrm{~min}$ or $120 \mathrm{~min}$ in $20 \mathrm{~mL}$ volume cultures, from which $2 \mathrm{~mL}$ aliquots were withdrawn at each time point. Samples treated with $\mathrm{NaCl}$ were harvested immediately after exposure ( $0 \mathrm{~min})$ and at 30, 60 and $120 \mathrm{~min}$, with unexposed controls monitored for an additional sample at 90 min. To study the effects of channel-modulating agents, culture aliquots were withdrawn also prior to treatment (-5 min). A short time-scale was preferred in these experiments since $\mathrm{Na}^{+}$ homeostasis mechanisms are known to be activated very quickly in cyanobacterial cells (4). Long-term adaptation, conversely, can result in the production of osmolytes or in the induction of different homeostatic responses rather then the cycling of $\mathrm{Na}^{+}$ ions $(4,17)$. Cultures were exposed to $\mathrm{NaCl}$ at $10 \mathrm{mM}$, lidocaine at $1 \mu \mathrm{M}$, amiloride at $1 \mathrm{mM}$, veratridine (VTD) at $100 \mu \mathrm{M}$, and saxitoxin (STX) at $1 \mu \mathrm{M}$. Concentrations of $\mathrm{NaCl}$ and channelmodulating agents were chosen based on previous studies on cyanobacteria $(8,18,19)$, and general physiological investigations on animal sodium channels (20-24). Samples withdrawn from cyanobacterial cultures were prepared and immediately analysed by flame photometry. This is an atomic emission technique for the routine detection of metal salts, principally $\mathrm{Na}, \mathrm{K}, \mathrm{Li}, \mathrm{Ca}$, and $\mathrm{Ba}$. Flame photometry is a simple, relatively inexpensive, high sample throughput method used for clinical, biological, and environmental analysis. This method has been preferred to the use of fluorescence probes in the study of total cyanobacterial $\mathrm{Na}^{+}-\mathrm{K}^{+}$levels.

\section{Effects of $\mathrm{pH}$ and $\mathrm{NaCl}$ on $\mathrm{Na}^{+}-\mathrm{K}^{+}$levels}

The imbalance of total cellular $\mathrm{Na}^{+}-\mathrm{K}^{+}$levels induced in $C$. raciborskii strain $\mathrm{T} 3$ by applied $\mathrm{pH}$ and sodium stresses is shown in Fig. 2. In response to rising alkalinity, $\mathrm{K}^{+}$levels had their maximum for optimal growth $\mathrm{pH}$ (7 to 10.5), but decreased for $\mathrm{pH}$ values higher than 11 . On the other hand, cellular $\mathrm{Na}^{+}$ content increased exponentially with the rising alkalinity of media, achieving the highest concentration at $\mathrm{pH}$ 12. Exposing C. raciborskii $\mathrm{T} 3$ cultures to $10 \mathrm{mM} \mathrm{NaCl}$ resulted in an increase of total $\mathrm{Na}^{+}$levels coupled with a corresponding decrease in cellular $\mathrm{K}^{+}$. The effects induced by salt stress on total cellular $\mathrm{Na}^{+}-\mathrm{K}^{+}$levels reached a maximum 30 min after the onset of the experiment, and slightly decreasing subsequently. This may indicate the activation of long-term adaptation mechanisms occurring only $60 \mathrm{~min}$ after the induction of a salt stress response. The highest and lowest values reached for the two ions over the samples at 0 min were $36 \%$ and $-25 \%$ for $\mathrm{Na}^{+}$and $\mathrm{K}^{+}$, respectively.
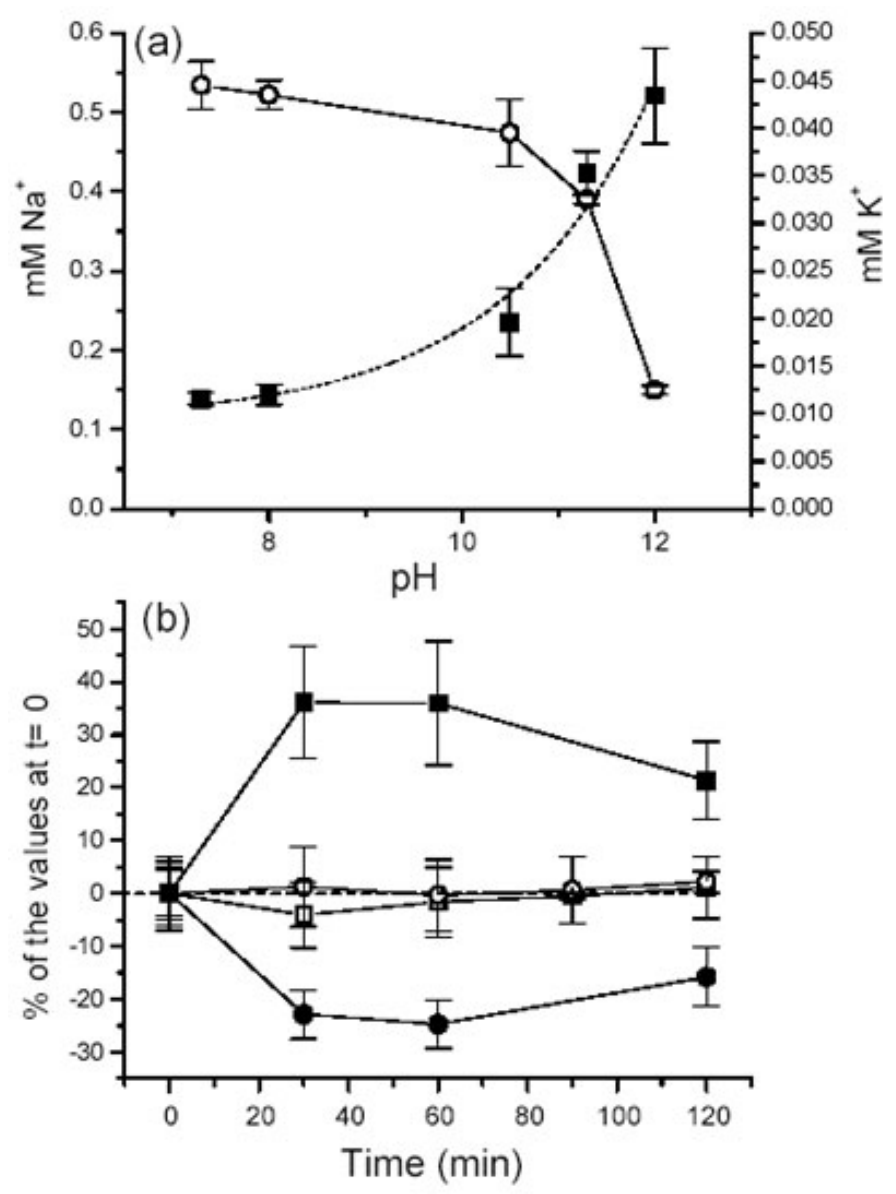

Fig. 2: (a) Total cellular $\mathrm{Na}^{+}(\mathbf{a})$ and $\mathrm{K}^{+}$(o) concentrations measured by flame photometry ( $\mathrm{mM} \pm$ Standard Error in the final cells suspension) in $C$. raciborskii strain $\mathrm{T} 3$ cell suspensions adjusted to different $\mathrm{pH}$ and analysed after $2 \mathrm{~h}$. (b) Time course of total cellular $\mathrm{Na}^{+}-\mathrm{K}^{+}$levels in $C$. raciborskii $\mathrm{T} 3$ cultures exposed to $10 \mathrm{mM} \mathrm{NaCl}$ for $2 \mathrm{~h}\left(\mathrm{Na}^{+}=\mathbf{m}, \mathrm{K}^{+}=\bullet\right)$, in comparison with untreated samples $\left(\mathrm{Na}^{+}=\square, \mathrm{K}^{+}=0\right)$; values are expressed as average percentile variation over the sample at $0 \mathrm{~min} \pm$ Standard Error.

\section{Effects of lidocaine and amiloride on $\mathrm{Na}^{+-} \mathrm{K}^{+}$levels}

To further investigate changes in $\mathrm{Na}^{+}$and $\mathrm{K}^{+}$cellular levels, we utilized amiloride at $1 \mathrm{mM}$ and lidocaine at $1 \mu \mathrm{M}$ to alter ion fluxes in C. raciborskii T3 over $2 \mathrm{~h}$ of exposure. Amiloride is a $\mathrm{Na}^{+}$channel-blocker that has been associated with the blockage of sodium channels utilized in the maintenance of $\mathrm{pH}$ and sodium homeostasis in eukaryotes (24) and prokaryotes (25), including the cyanobacterium Synechocystis PCC 7120 (4). Lidocaine is a medical local anaesthetic and its physiological effect is related to the blockage of animal sodium channels (16). Additionally, lidocaine hydrochloride has been shown to interfere with the activity of $\mathrm{Na}^{+} / \mathrm{H}^{+}$antiporters in several other organisms $(23,26,27)$. According to the model of alkaline $\mathrm{pH}$ and $\mathrm{Na}^{+}$homeostasis previously introduced, the inhibition of $\mathrm{Na}^{+} / \mathrm{H}^{+}$antiporters would result in a net $\mathrm{Na}^{+}$intracellular accumulation, while the blockage of sodium uptake would lead to 
a concomitant cytoplasmic decrease in this ion. Here we show that amiloride and lidocaine can interfere with cyanobacterial $\mathrm{Na}^{+}$ uptake and $\mathrm{Na}^{+}$export mechanisms, respectively, affecting in opposite ways the total cellular sodium concentrations (Fig. 3).

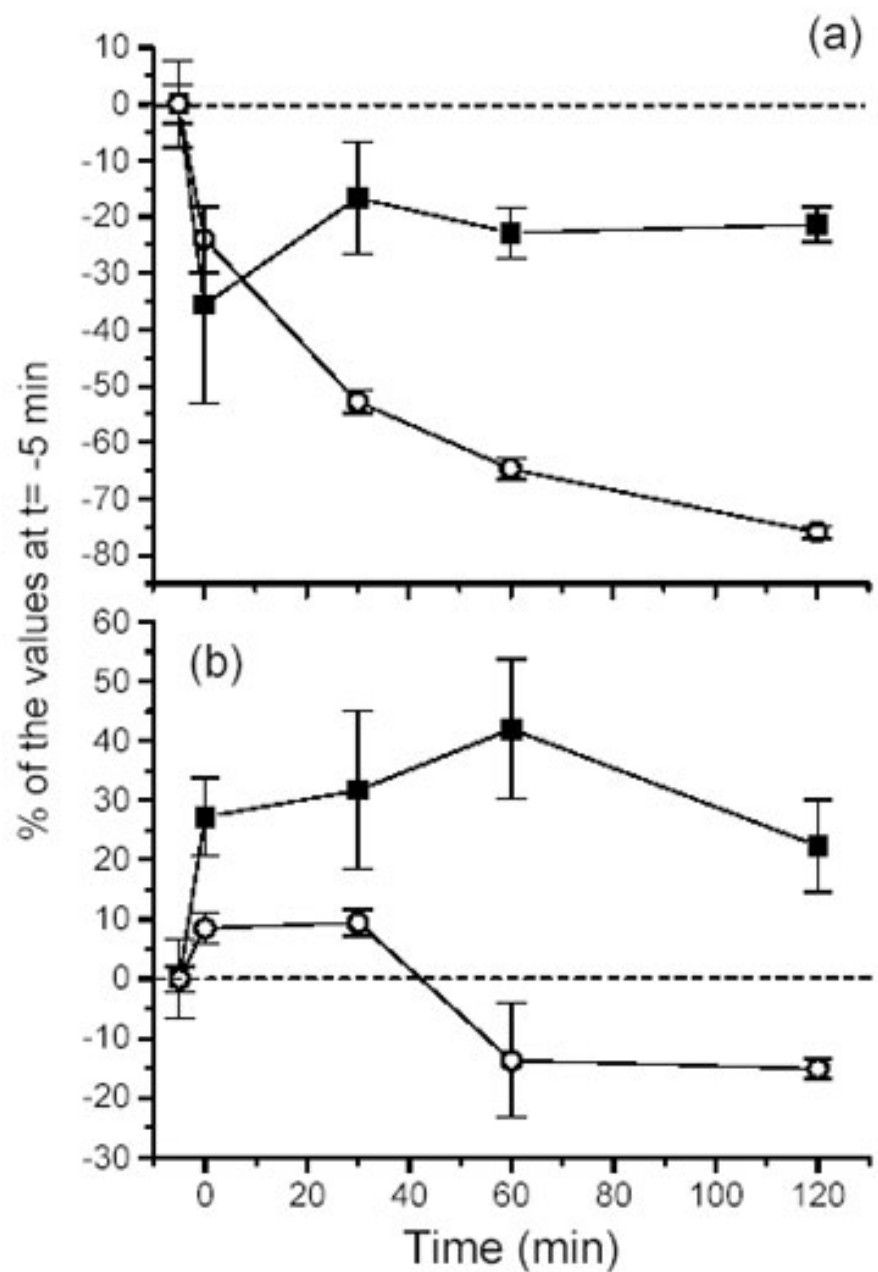

Fig. 3: Effects of amiloride at $1 \mathrm{mM}$ (a) and lidocaine hydrochloride at 1 $\mu \mathrm{M}$ (b) on the total cellular $\mathrm{Na}^{+}(\mathbf{})$ and $\mathrm{K}^{+}$(o) levels in $C$. raciborskii strain T3 cultures. Values are expressed as average percentile variation over the sample at $-5 \mathrm{~min} \pm$ Standard Error.

The two sodium channel blockers elicited a rapid response by ion cycles, as seen by comparison of $\mathrm{Na}^{+}$and $\mathrm{K}^{+}$values at -5 min and $0 \mathrm{~min}$ (i.e., immediately after addition of the blockers). Amiloride at $1 \mathrm{mM}$ (Fig. 3A) induced a decrease in total cellular $\mathrm{Na}^{+}$and $\mathrm{K}^{+}$levels. However, $\mathrm{Na}^{+}$values diminished by only $21 \%$ after $2 \mathrm{~h}$, while $\mathrm{K}^{+}$content decreased to $-76 \%$ of samples at -5 min. This may indicate a more specific effect of amiloride for $\mathrm{K}^{+}$ rather than $\mathrm{Na}^{+}$uptake mechanisms. Lidocaine hydrochloride at $1 \mu \mathrm{M}$, in contrast, promoted the cellular increase of both $\mathrm{Na}^{+}$ and $\mathrm{K}^{+}$values within 30 minutes (Fig. 3B). Potassium ions eventually decreased to control levels after 60 minutes, with the highest and lowest values reached for $\mathrm{Na}^{+}$and $\mathrm{K}^{+}$, compared with samples at $-5 \mathrm{~min}$, of $42 \%$ and $-15 \%$ at 60 and 120 minutes, respectively.

\section{Effects of veratridine and saxitoxin on $\mathrm{Na}^{+}-\mathrm{K}^{+}$ levels}

STX, one of the most potent natural neurotoxic alkaloids (28), selectively blocks voltage-gated $\mathrm{Na}^{+}$channels in excitable cells (21). This toxin acts from the extracellular side of the plasma membrane by occluding the entry of the sodium channel pore. VTD is a $\mathrm{Na}^{+}$channel activator that binds to the inner side of the sodium channel pore. By its action, VTD alters the channel activation kinetics and inhibits the sodium channel inactivation, thereby increasing $\mathrm{Na}^{+}$permeability in eukaryotic cells (20). In $C$. raciborskii strain AWT205, the stress induced by $10 \mathrm{mM} \mathrm{NaCl}$ increased total cellular $\mathrm{Na}^{+}$levels compared to the untreated controls (Fig. 4A).

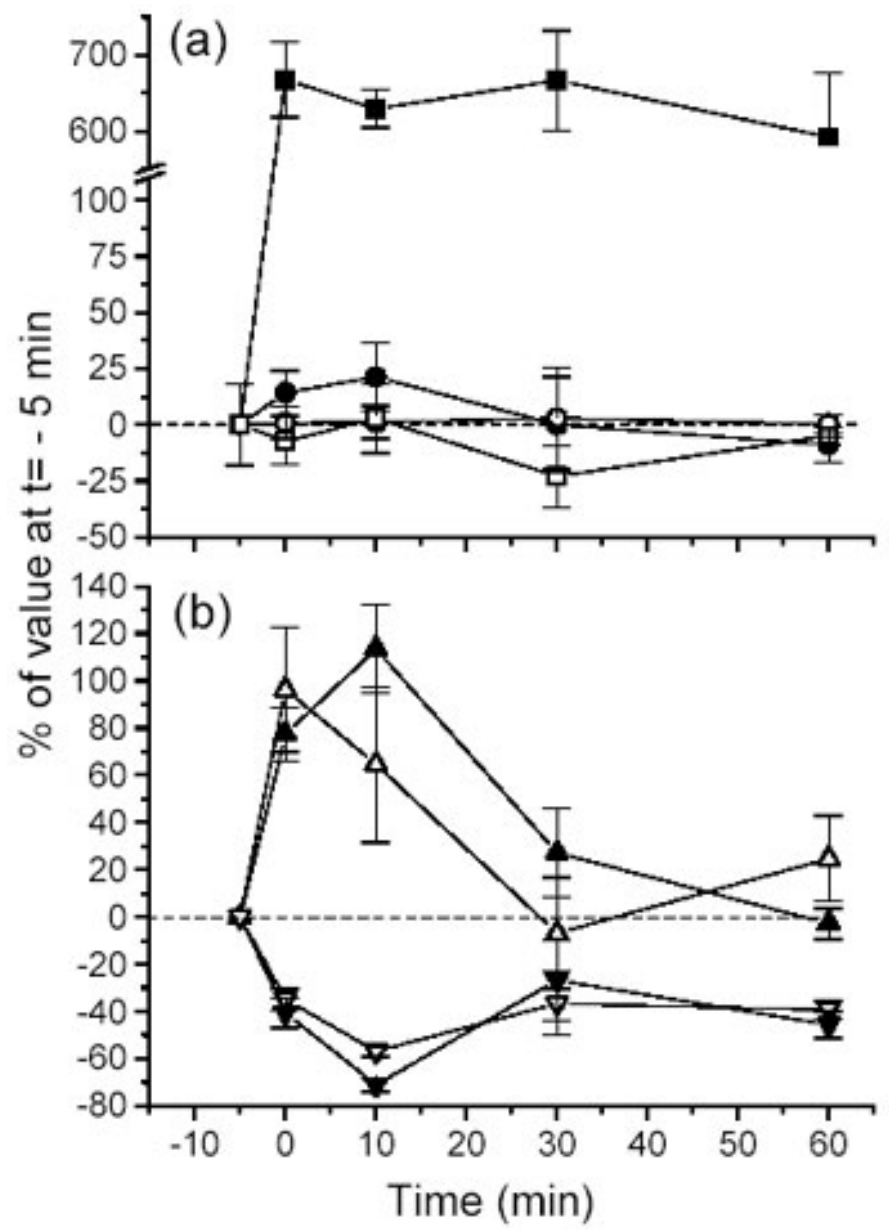

Fig. 4: (a) Time course of total cellular $\mathrm{Na}^{+}-\mathrm{K}^{+}$levels in $C$. raciborski strain AWT205 cultures exposed to $10 \mathrm{mM} \mathrm{NaCl}\left(\mathrm{Na}^{+}=\mathbf{m}, \mathrm{K}^{+}=\square\right)$ in comparison with untreated control samples $\left(\mathrm{Na}^{+}=\boldsymbol{\bullet}, \mathrm{K}^{+}=\mathbf{0}\right)$. (b) Effects of STX at $1 \mu \mathrm{M}\left(\mathrm{Na}^{+}=\boldsymbol{\nabla}, \mathrm{K}^{+}=\nabla\right)$ and VTD at $100 \mu \mathrm{M}\left(\mathrm{Na}^{+}=\boldsymbol{\Delta}, \mathrm{K}^{+}=\Delta\right)$ on total cellular $\mathrm{Na}^{+}-\mathrm{K}^{+}$concentrations in C. raciborskii AWT205. Values are expressed as average percentile variation over the sample at $-5 \mathrm{~min} \pm$ Standard Error.

$\mathrm{Na}^{+}$uptake by the cells was shown to be very rapid, and the total cyanobacterial sodium content remained stable over the $60 \mathrm{~min}$ course of the experiment. Total $\mathrm{K}^{+}$content of cells was only slightly affected by $10 \mathrm{mM} \mathrm{NaCl}$, suggesting that the homeostasis 
of $\mathrm{K}^{+}$is of marginal consequence in the $\mathrm{Na}^{+}$stress response of this strain. On the other hand, both $\mathrm{Na}^{+}$and $\mathrm{K}^{+}$cellular levels were altered due to the effects of STX at $1 \mu \mathrm{M}$ and VTD at 100 $\mu \mathrm{M}$ (Fig. 4B). The addition of VTD dramatically stimulated cyanobacterial $\mathrm{Na}^{+}-\mathrm{K}^{+}$accumulation while STX markedly inhibited the cellular uptake and hence intracellular levels of both ions. The observed opposing effects of STX and VTD on cyanobacterial $\mathrm{Na}^{+}-\mathrm{K}^{+}$ion fluxes were rapid but not $\mathrm{Na}^{+}$ specific, as predicted by the interaction of these compounds with eukaryotic cells. These results suggest that, in cyanobacteria, $\mathrm{Na}^{+}$ flux is not the only cellular response elicited by these two compounds. Furthermore, STX and VTD may have less specific effects on prokaryotic cells than those reported in the literature for eukaryotic sodium fluxes, or the target of these two agents on cyanobacterial cells may be a binding protein involved in both $\mathrm{Na}^{+}$and $\mathrm{K}^{+}$homeostasis. The latter hypothesis is consistent with several reports in the literature demonstrating the presence, in cyanobacterial cells, of channel proteins permeable to both sodium and potassium ions (29-31).

\section{Culturing factors that can influence response}

Cyanobacterial growth can be affected by a variety of factors, that can determine substantial changes in the physiological response. Alkaline $\mathrm{pH}$ represents one of the most critical among these factors. To facilitate cyanobacterial growth and to maintain an active $\mathrm{Na}^{+}$cycle, it is necessary to maintain the $\mathrm{pH}$ level above 8. As seen in Fig. 2A, however, a change in 1 unit of $\mathrm{pH}$ could result, in extreme alkaline conditions, in a 2 to 3 fold increase in cellular $\mathrm{Na}^{+}$levels. For this reason, the use of buffers with $\mathrm{pH}$ range from 8 to 9 is critical for these kinds of experiments. Similarly, culture media too rich in nutrients, salts, or $\mathrm{NaHCO}_{3}$ should be avoided. In addition, varying light intensity or photoperiod could result in substantial changes in the cyanobacterial physiological response to $\mathrm{pH}, \mathrm{Na}^{+}$stress or ionchannel modulating agents. As previously mentioned, cyanobacterial homeostasis mechanisms can be energized by an imposed proton motive force $(6,7)$, which is principally derived from photosynthetic activity.

\section{Reproducibility and statistics}

Reproducibility from laboratory to laboratory of the physiological investigations performed in this study can be influenced by the nature of the strain utilized. As seen in Figs. 2B and 4A, different strains of the same species may respond to applications of the same stress in quantitatively diverse measures. Heterogeneity in the response, in this case, reflects both the origin and the genetic background of the two strains employed (11, 12, 32). Additionally, as mentioned earlier, reproducibility can be influenced by the interplay between the different culturing and inducing factors. Together with inter-strain heterogeneity, intrastrain phenotypic-switching phenomena can also occur. After generations of lab-culturing, although it is uncommon, it has been documented that sub-cultures may diverge from the originals with respect to certain physiological functions, such as the production of secondary metabolites (33). In this study, experiments were performed in replicates maintained in identical conditions. In some instances, however, we observed samples eliciting no expected response, and possible explanations for these occurrences range from rare contamination to experimental inaccuracies and unknown biological factors. We strongly suggest, therefore, to approach similar investigations performing replicate experiments, repeating them at least twice, with samples prepared in duplicate or triplicate for a final data set of four to six replicates. This allows the use of statistical analysis such as ANOVA, and a more sound interpretation of results.

\section{CONCLUSIONS}

The present paper indicates, as summarised in Table 1, the usefulness of well-defined pharmaceuticals for studying cyanobacterial physiology. Traditionally, this type of study would have been approached by varying known ecological parameters. Ion-channel modulating agents are a potential tool to further investigate aspects of the cyanobacterial stress response and related metabolisms. The experimental design proposed can be applied to other cyanobacterial species, algae or bacteria. Results revealed here also indicate an association between prokaryotic and eukaryotic alkaline $\mathrm{pH} / \mathrm{Na}^{+}$homeostasis, an association that may also suggest analogies in ion channel structures and functions.

Table 1: Properties of the agents used in this investigation, with respect to their primary effects on eukaryotic cells and their effect on $\mathrm{Na}^{+}$and $\mathrm{K}^{+}$fluxes, as observed in this study.

\begin{tabular}{|c|c|c|c|}
\hline Agent & $\begin{array}{l}\text { Concen- } \\
\text { tration }\end{array}$ & $\begin{array}{l}\text { Principal effect on } \\
\text { eukaryotic cells }\end{array}$ & $\begin{array}{c}\text { Effect on } \\
\text { cyanobacteria }\end{array}$ \\
\hline Amiloride & $1 \mathrm{mM}$ & $\begin{array}{c}\text { Blockage of epithelial } \\
\text { mechano-sensitive } \mathrm{Na}^{+} \\
\text {channels }\end{array}$ & $\begin{array}{l}\text { Decreases both } \mathrm{Na}^{+} \\
\text {and } \mathrm{K}^{+} \text {uptake }\end{array}$ \\
\hline Lidocaine & $1 \mu \mathrm{M}$ & $\begin{array}{l}\text { Blockage of } \mathrm{Na}^{+} \text {channels } \\
\text { in neurons }\end{array}$ & $\begin{array}{c}\text { Increases } \mathrm{Na}^{+} \text {uptake, } \\
\text { decreases } \mathrm{K}^{+} \text {uptake }\end{array}$ \\
\hline Saxitoxin & $1 \mu \mathrm{M}$ & $\begin{array}{l}\text { Blocks voltage-gated } \mathrm{Na}^{+} \\
\text {channels }\end{array}$ & $\begin{array}{l}\text { Decreases both } \mathrm{Na}^{+} \\
\text {and } \mathrm{K}^{+} \text {uptake }\end{array}$ \\
\hline Veratridine & $100 \mu \mathrm{M}$ & $\begin{array}{l}\text { Maintains voltage-gated } \mathrm{Na}^{+} \\
\text {channels in activation state }\end{array}$ & $\begin{array}{l}\text { Increases both } \mathrm{Na}^{+} \\
\text {and } \mathrm{K}^{+} \text {uptake }\end{array}$ \\
\hline
\end{tabular}

\section{ACKNOWLEDGMENTS}

This work was funded by the Australian Research Council, and the authors are grateful to C. Rossetti and G. Manarolla for advice and experimental assistance. The authors have no conflicts of interest to declare related to this publication.

\section{REFERENCES}

1. Horikoshi K. Microorganisms in alkaline environments. New York: VCH;1991. p. 110. 
2. Krulwich TA, Ito M, Guffanti AA. The $\mathrm{Na}^{+}$-dependence of alkaliphily in Bacillus. Biocbim Biophys Acta 2001; 1505:158168.

3. Lengeler JW, Drews G, Schlegel HG. Biology of the Prokaryotes. Oxford: Blackwell Science; 1999. p. 269.

4. Maestri O, Joset F. Regulation by external $\mathrm{pH}$ and stationary growth phase of the acetolactate synthase from Synechocystis PCC6803. Mol Microbiol 2000; 37:828-838.

5. Waditee R, Hibino T, Tanaka $\mathrm{Y}$, Nakamura $\mathrm{T}$, Incharoensakdi A, Takabe T. Halotolerant cyanobacterium Aphanothece halophytica contains an $\mathrm{Na}^{+} / \mathrm{H}^{+}$antiporter, homologous to eukaryotic ones, with novel ion specificity affected by C-terminal tail. J Biol Chem 2001; 276:3693136938.

6. Apte SK, Thomas J. Membrane electrogenesis and sodium transport in filamentous nitrogen-fixing cyanobacteria. Eur J Biochem 1986; 154:395-401.

7. Sonoda M, Katoh H, Vermaas W, Schmetterer G, Ogawa T. Photosynthetic electron transport involved in PxcAdependent proton extrusion in Synechocystis sp. strain PCC6803: effect of pxcA inactivation on $\mathrm{CO}^{2}, \mathrm{HCO}^{3-}$, and $\mathrm{NO}^{3-}$ uptake. J Bacteriol 1998; 180:3799-3803.

8. Miller AG, Turpin DH, Canvin DT. $\mathrm{Na}^{+}$requirement for growth, photosynthesis, and $\mathrm{pH}$ regulation in the alkalotolerant cyanobacterium Synechococcus leopoliensis. J Bacteriol 1984; 159:100-106.

9. Ren D, Navarro B, Xu H, Yue L, Shi Q, Clapham DE. A prokaryotic voltage-gated sodium channel. Science 2001; 294:2306-2308.

10. Koishi R, Xu H, Ren D, Navarro B, Spiller BW, Shi Q, Clapham DE. A superfamily of voltage-gated sodium channels in bacteria. J Biol Chem 2004; 279:9532-9538.

11. Humpage AR, Rositano J, Bretag A, Brown R, Baker P, Nicholson BC, Steffensen DA. Paralytic shellfish poisons from Australian cyanobacterial blooms. Aust J Mar Freshwater Res 1994; 45:761-771.

12. Hawkins PR, Chandrasena NR, Jones GJ, Humpage AR, Falconer IR. Isolation and toxicity of Cylindrospermopsis raciborskii from an ornamental lake. Toxicon 1997; 35:341-346.

13. Lagos N, Onodera H, Zagatto PA, Andrinolo D, Azevedo SMFQ, Oshima Y. The first evidence of paralytic shellfish toxins in the freshwater cyanobacterium Cylindrospermopsis raciborskii, isolated from Brazil. Toxicon 1999; 37:1359-1373.

14. Bowling LC, Baker PD. Major cyanobacterial bloom in the Barwon-Darling River, Australia, in 1991, and underlying limnological conditions. Mar Freshwater Res 1996; 47:643-657.

15. Gorham PR, McLachlan J, Hammer UT, Kim WK. Isolation and culture of toxic strains of Anabaena flos-aquae (Lyngb.) de Breb. Verh. Int Verein Theor Angew Limnol 1964; 15:796-804.

16. Hille B. Ionic Channels of Excitable Membranes. 2nd Edition. Sunderland: Sinauer Associates; 1997. p. 224.

17. Quintero MJ, Muro-Pastor AM, Herrero A, Flores E. Arginine catabolism in the cyanobacterium Synechocystis sp. strain PCC6803 involves the urea cycle and arginase pathway. J Bacteriol 2000; 182:1008-1015.

18. Kanesaki Y, Suzuki I, Allakhverdiev SI, Mikami K, Murata N. Salt stress and hyperosmotic stress regulate the expression of different sets of genes in Synechocystis sp. PCC 6803. Biochem Biophys Res Commun 2002; 290:339-348.

19. Pomati F, Neilan BA, Manarolla G, Suzuki T, Rossetti C. Enhancement of intracellular saxitoxin accumulation by lidocaine hydrochloride in the cyanobacterium Cylindrospermopsis raciborskii T3 (Nostocales). J Phycol 2003; 39:535-542.

20. Catteral WA, Nirenberg M. Sodium uptake associated with activation of action potential ionophores of cultured neuroblastoma and muscle cells. Proc Natl Acad Sci USA 1973; 70:3759-3763.

21. Catterall WA. Neurotoxins that act on voltage-sensitive sodium channels in excitable membranes. Annu Rev Pharmacol Toxicol 1980; 20:15-43.

22. Kim D, Smith TW. Effects of amiloride and ouabain on contractile state, $\mathrm{Ca}$ and $\mathrm{Na}$ fluxes, and $\mathrm{Na}$ content in cultured chick heart cells. Mol Pharmacol 1986; 29:363-371.

23. Shibamoto S, Hori T, Hayakawa M, Nango M, Cragoe EJ Jr, Oku N, Ito F. Inhibitory effect of local anesthetics on $\mathrm{Na}^{+} / \mathrm{H}^{+}$antiporter in brush border membrane-reconstituted vesicles. Life Sci 1990; 47:1129-1133.

24. Schaefer L, Sakai H, Mattei MG, Lazdunski M, Lingueglia E. Molecular cloning, functional expression and chromosomal localization of an amiloride-sensitive $\mathrm{Na}^{+}$channel from human small intestine. FEBS Letters 2001; 471:205-210.

25. Rowbury RJ, Goodson M, Humphrey TJ. Sodium chloride induces an $\mathrm{NhaA} / \mathrm{NhaR}$-independent acid sensitivity at neutral external $\mathrm{pH}$ in Eschericbia coli. Appl Environ Microbiol 1994; 60:1630-1634.

26. Nosaka S, Ohkawa TA, Okihara K, Yoshikawa K. Effects of local anesthetics on the Chara plasmalemma. Biocbim Biophys Acta 1992; 1106:325-334.

27. Bidani A, Heming TA. Effects of lidocaine on cytosolic $\mathrm{pH}$ regulation and stimulus-induced effector functions in alveolar macrophages. Lung 1997; 175:349-361.

28. Strichartz G. Relative potencies of several derivates of saxitoxin: electrophysiological and toxin binding studies. Biophys J 1981; 33:209-216.

29. Kaneko T, Sato S, Kotani H, Tanaka A, Asamizu E, Nakamura Y, Miyajima N, Hirosawa M, Sugiura M, Sasamoto S, Kimura T, Hosouchi T, Matsuno A, Musaraki A, Nakazaki N, Nauro K, Okumura S, Shimpo S, Takeuchi C, Wada T, Watanabe A, Yamada M, Yasuda M, Tabata S. Sequence analysis of the genome of the unicellular cyanobacterium Synechocystis sp. PCC6803: II. Sequence determination of the entire genome and assignment of potential protein coding regions. DNA Res Suppl 1996; 3:741-747.

30. Murata T, Takase K, Yamato I, Igarashi K, Kakiuma Y. The $n t p J$ gene in the Enterococcus hirae ntp operon encodes a component of KtrII potassium transport system functionally independent of vacuolar Na+-ATPase. J Biol Chem 1996; 271:10042-10047.

31. Nakamura T, Yuda R, Unemoto T, Bakker EP. KtrAB, a new type of bacterial $\mathrm{K}+$-uptake system from Vibrio alginolyticus. J Bacteriol 1998; 180:3491-3494. 
32. Neilan BA, Saker ML, Fastner J, Torokne A, Burns BP. Phylogeography of the invasive cyanobacterium Cylindrospermopsis raciborskii. Mol Ecol 2003; 12:133-140.

33. Martins CA, Kulis D, Franca S, Anderson DM. The loss of PSP toxin production in a formerly toxic Alexandrium lusitanicum clone. Toxicon 2004; 43:195-205.

34. Shibata M, Katoh H, Sonoda M, Ohkawa H, Shimoyama M, Fukuzawa H, Kaplan A, Ogawa T. Genes Essential to Sodium-dependent Bicarbonate Transport in Cyanobacteria.
Function and phylogenetic analysis. I Biol Chem 2002; 277:18658-18664.

35. Kaneko T, Nakamura Y, Wolk CP, Kuritz T, Sasamoto S, Watanabe A, Iriguchi M, Ishikawa A, Kawashima K, Kimura T, Kishida Y, Kohara M, Matsumoto M, Matsuno A, Muraki A, Nakazaki N, Shimpo S, Sugimoto M, Takazawa M, Yamada M, Yasuda M, Tabata S. Complete genomic sequence of the filamentous nitrogen-fixing cyanobacterium Anabaena sp. strain PCC 7120. DNA Res 2001; 8:205-213. 